\title{
Several Aspects of Digital Transformation in State Administration of Rational Agricultural Land Use
}

\author{
Danilenko A.S, Satyr L.M, Novikova V.V., Shust O.A.
}

\begin{abstract}
The concept of land management and rational land use is defined. The influence of digitization on the state administration of rational use of agricultural land is investigated. The analysis of the development of electronic administrative services in the field of land relations of Ukraine on the principle of its extraterritoriality is carried out. Modern ways of counteracting irrational conduct of agrarian activity on the state level have been revealed. Methods of stimulating responsible use of land resources by agricultural producers are investigated. The problems of environmental management at the level of economic entities are explored that mainly covers the principles, peculiarities of positioning and the importance of prudent use of agricultural land. The necessity of fixing the principles of stimulating the process of efficient and environmentally friendly land use in the agricultural sphere on the state level is substantiated.
\end{abstract}

Keywords: digitalization, digital technologies, environmental management, state administration, rational use of land resources.

Keywords: digitalization, environmental management, state administration, rational use of land resources.

\section{INTRODUCTION}

During the period of independence, the portrait of primary splitting of agricultural land and the collapse of collective farms to the formation of large agricultural holdings and the introduction of modern digital technologies. Currently, most agricultural producers in Ukraine operate unmanned aerial vehicles for spraying pesticides on agricultural land, sensors for monitoring soil and crops, electronic weather stations, automatic irrigation systems for agricultural land, satellite farming, etc. In the epoch of digital economy of Ukraine, digitization optimizes business processes in agriculture, manages its resources, controls the quality of agricultural products and introduces new strategies for agricultural producers.

At the same time, climate changes increasingly have influence on the use of agricultural land and in its turn the rational use of agricultural land has influence on the climate. Reduction of the greenhouse gas emissions into the

Revised Version Manuscript Received on October 15, 2019. Bila Tserkva, Ukraine, Email: rectorat@ btsau.net.ua

Larysa Satyr. Head of the Department of Business, Trade and Exchange Activity, Bila Tserkva National Agrarian University, Bila Tserkva, Ukraine, Email: Lasatyr@i.ua

Victoria Novikova. Lecturer at the Department of Information Systems and Technologies, Bila Tserkva National Agrarian University, Bila Tserkva, Ukraine, Email: novikova.v@i.ua

Olena Shust. Professor at the Department of Economics and Economic Theory, Bila Tserkva National Agrarian University, Bila Tserkva, Ukraine, Email: elenshust@mail.ru Ukrainian agricultural producers has changed from the Anatoliy Danylenko. President, Bila Tserkva National Agrarian University,

atmosphere, transition to renewable energy sources, investing in the ecology of agricultural processes are no longer goodwill, but a obligatory terms for global agricultural players. Thus, the majority of Ukrainian rapeseed exports go to the European Union countries, which have severe restrictions on greenhouse gas emissions from biofuel production. It should be noted that Ukrainian rapeseed emissions require farmers to make significant investments or search for other, less principled markets for its sales. In addition, Ukraine is increasing the area of agricultural land for growing not only rapeseed, but also relatively profitable sunflowers and maize, which without actual crop rotation reduce the moisture balance and soil fertility.

Therefore, the state management of land resources in modern conditions of economy becomes especially relevant. Land is the main resource for agriculture. In its turn, agricultural production is the basis of the food security of the state, a prerequisite for the economic development and social well-being of any country, and therefore the distribution and control of the use of agricultural land resources is carried out on the state level under the close supervision of the public and different controlling bodies. In addition, environmental problems due to neglect of agricultural land and the principles of environmental management in the process of agricultural production, as well as the difficult economic conditions that Ukrainian farmers currently find themselves in, need of revising and expanding the list of tools to encourage rational land use on the state level.

The principles of rational land use in Ukraine are laid in the scientific works of such a researcher as Garnag O. [1]. The role of the state in the process of providing the rational use of land resources is defined in the works of such scientists as Isachenko O.P., Semochkin V.M. [2] Yevtushenko M. [3]. Economic aspects of stimulating the rational use of agricultural land are considered by Brindzia O.Z. in the researching the economic levers of a systematic approach to rational agricultural land use [4], Palenychak O.V. in the researching the economic mechanism of stimulating rational agricultural land use [5], Stupen M. and Skorupska O., who concretize the economic aspects of the rational use of agricultural land [6], Shashula LA, specifying the role of organic land use in the economic providing the rational use of nature [7]. 
Without diminishing the role of scientific work which are directed on the study of the theory and practice of state administration of rational agricultural land use, a wide range of issues about the rational use of land in agriculture with respect to environmental management and use of digital technologies remains unexplored.

The purpose of the research is to concretize the environmental, socio-economic and technological aspects of the state administration of rational agricultural land use in the conditions of development of digital economy.

Research methods will be: methods of induction and deduction, scientific abstraction and generalization, method of ordering, methods of analysis and synthesis.

\section{RESULTS AND DISCUSSION}

Generally, land management should be understood as the permanent, systematic, conscious and purposeful influence of the state in the face of responsible authorities and society on relationships of land use. The process is based on objective laws to provide the rational use of land resources of the state. In view of this, land use is offered to understand as the most effective (from the point of view of satisfying the needs of the state and society) method of involving them in production processes taking into account natural, economic, political, environmental and social conditions of economy in nature and society.

The effective use of land in the context of interaction between society and nature, digital economy and ecology implies the influence on this process of the following aspects (Fig. 1):

- natural and biological, which is connected with the research of the functioning of the land as a component of the natural complex and environment for the development of alive organisms;

- socio-economic, which reflects the influence on the land use of social, state-political processes, social relationships that form the economic side of land use as an economic resource;

- technological, that is related to the development of opportunities for technical influence on the land, the method of use, the relationship of rational use of land resources with the use of scientific and technical developments;

- legal, which is based on the research of the importance of the legal influence of the executive power and local self-government on the organization and implementation of rational development, use and protection of land;

- environmental, which is related to the influence of agricultural production on the state of the environment in the region and the country as a whole.

The necessity of rational land use is being updated at a time when the global digital economy is increasing, giving huge benefits to countries that have direction on digitalization: a profound transformation of public administration that involves the use of digital technologies to optimize administrative processes, to increase administrative efficiency and to improve the experience of interaction with civil society.

Today Britain, Estonia, Israel, New Zealand, UAE, Singapore and Japan are leaders in the development of the digital economy, instead Ukraine, only from 2018, has taken accordance with existing principles of interaction between

a course on building a digital economy at the national level. In most countries, digitalization is an area of active government policy that, due to access to capital, tax credits and other benefits, stimulates business and citizens to build a digital economy, builds a national digital infrastructure and engages private investors in the process of creating digital platforms. However, the development of digital infrastructures concerning identification and trust, open data, public services and e-government, etc., is complicated by the uneven development of fixed broadband Internet infrastructure in urban and rural areas of Ukraine [8].

Today, given the need for the development of an ecological state in Ukraine, digitization has considerable potential for improving the state administration of rational agricultural land use (Fig. 1). Thus, the main directions of influence of digitalization in state administration on the process of rational use of agricultural lands are rational and responsible use and availability of agricultural lands; rational use of agricultural land, improving the efficiency of agricultural production and supply of agricultural products; rational holistic planning and management of the process of agricultural land use; providing the purity of agricultural land; rational use of agricultural land and prevention of biodiversity loss.

Therefore, at the time of creation of the national system of independent environmental monitoring and evaluation of the conditions of agricultural lands, as well as electronic registers of agricultural lands for the purpose to provide information about the state administration of rational use of agricultural land, since the essential cause of irrational land use is undoubtedly different of land particles (units).

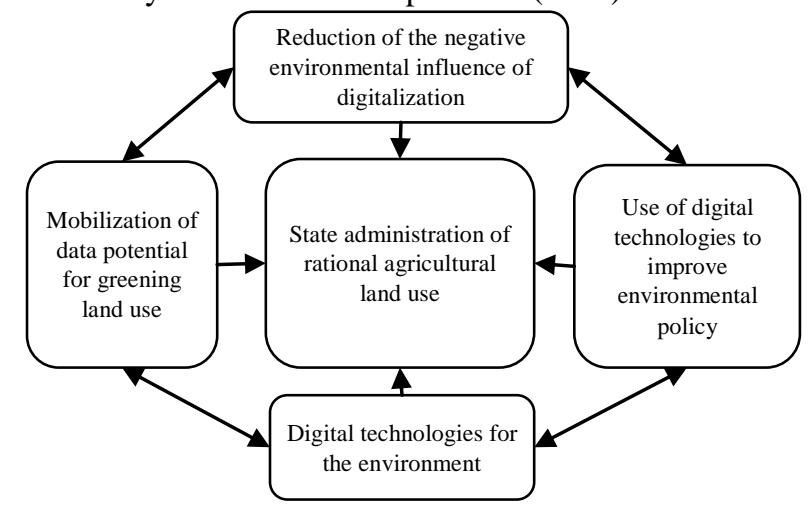

Fig. 1. Influence of digitalization on state administration of rational agricultural land use

One of the measures that can help to solve this problem at the state level is to provide the development of documentation about the land management, which helps for the formation and registration in the state land cadaster of all land plots.

It should be noted that since the beginning of 2013 an electronic register of land resources (the so-called State Land Cadaster) has been operating in Ukraine since the Law of Ukraine "On the State Land Cadaster" enacted in 2011 came into force. In 2017, using the blockchain technology, an updated version of the geoinformation system of the 
electronic land registry was implemented. From now on, the State Land Cadaster has acquired the status of a single state geoinformation system (Fig. 2), which contains information about lands that are located on the territory of Ukraine, its purpose, data about the quantitative and qualitative characteristics of land, its evaluation, etc.

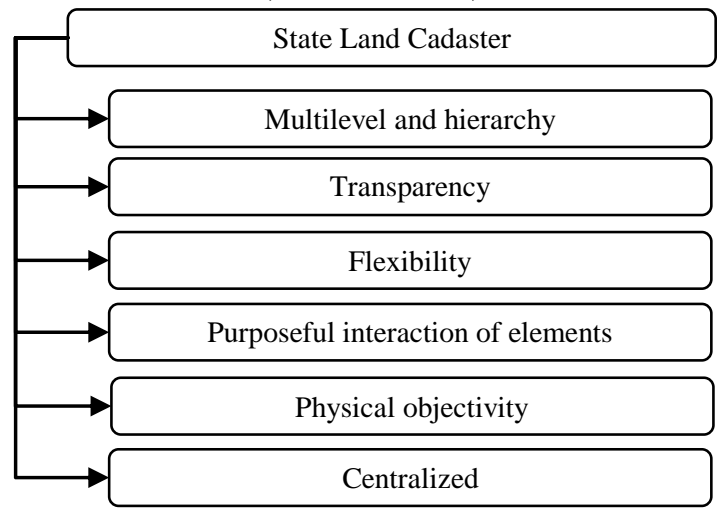

Fig. 2. Characteristics of State Land Cadaster as geoinformation system of land relations

The information of the State Land Cadaster is in the form of the Public Cadaster Map of Ukraine today. In addition, the State service of Ukraine for Geodesy, Cartography and Cadaster performs, on a paid basis, orders for extraction from the State Land Cadaster of the requested land plot, free orders of extracts for the regulatory monetary valuation of the required land plot, provides information about land owners and land users, and makes access for notaries to the electronic register of land resources, etc. [9]. Most of the electronic services of the State service of Ukraine for Geodesy, Cartography and Cadaster are accessible through the identification of applicant with the use by him of electronic digital signature or his identification with the bank card.

The State Land Cadaster as a geoinformation system of land relations in Ukraine is characterized by:

- flexibility as an opportunity to change the functioning of this information system in the dependence on the tasks;

- physical objectivity, which is based on the masses of information that characterize land plots as specific objects of accounting;

- multilevel and hierarchy, which guarantee high reliability of the information system functioning;

- transparency, which provides the constant exchange and updating of information due to the interaction of the electronic land registry with other resources of the digital state [10].

Geoinformation system of The State Land Cadaster, which is built on the basis of modern information technologies, makes it possible to quickly obtain the requested information about land plots within the territory of Ukraine through the use of information about land resources that is displayed on the Public Cadaster Map of Ukraine. In view of this, such a post-Soviet model of digital transformation in the state administration of rational agricultural land use places first the establishment of information interaction between different authorities and their subordinate agencies in the field of land relations in order to increase the efficiency of state land management, to provide free access to necessary information and administrative services through the official website in the Internet [11].
Today, the State Land Cadaster successfully serves agricultural land leasing operations. However, the opening of the agricultural land market will stimulate filling the electronic land registry with quality information, because in the absence of a cadastral number of the land plot or the presence of geometry errors in the information of such a cadaster, the seller of the land plot is interested in land restoration, as well as its registration in the State Land Cadaster already with reliable characteristics.

Obviously, the activities of the State service of Ukraine for Geodesy, Cartography and Cadaster should be brought into compliance with the current legislation, and the State Land Cadaster itself should not perform a purely legal and fiscal function, and therefore should provide information support for environmental safety, the rational use of agricultural land and the sustainable development of rural areas. For this purpose it is necessary to conduct a complete inventory of all land plots within the territory of the state, to ensure transparency of the agricultural land market and to introduce mechanisms of preventive protection of landowners from price speculation, to simplify the procedures of land transactions, to improve the mechanism of land mortgage with local registration by real placement [12].

In addition, measures that can help address the problem of irrational land use on the state level include the following: compliance with agricultural land use intensity standards and formation of the investment attractiveness of land use.

Along with all the above-mentioned measures to rationalize the use of land plots, an effective method to improve the efficiency of agricultural land use is to order land payments in the form of tax, rent, fee for perpetual lease and compensation payments.

The main factor in ordering land payments is its differentiation not only on the basis of common peculiarities of quality and location of land, but also with regard to regional conditions and specific land use. In particular, it is necessary to consider zoning of land by suitability, location of land plot; to evaluate measures for elimination of soil pollution, conservation and increase of soil fertility, volume of legal powers of land owners and users, results of economic activity of agricultural producers.

The rational use of land is important not only for achieving the economic effect of conducting agricultural activities and preserving the strategic resources of the state, but also for stabilizing the environmental situation both locally and globally. Ecologically oriented economic development, greening of production are recognized as important tasks of environmental management mechanisms in many countries of the world. In Ukraine, environmental management is positioned as the implementation of a set of measures aimed at planning, organizing, implementing and controlling the process of protecting the environment from the negative influence of human economic activity. One of the economic activities is the production of agricultural products, which allows to conduct research on the chosen scientific topic in the context of the need to take into account the tasks of environmental management. 
The issues of environmental management are researched on the level of economic entities, and on the state level it is not given sufficient attention, although the rational use of any resource of national importance is one of the tasks of state management of the macroeconomic system. Against this background, we consider providing the efficient use of agricultural land as one of the strategic directions of state administration, which should contribute to the achievement of the goals of environmental management in a local and global scale.

Proper use of agricultural land aims taking into account natural factors, so as climatic, soil, availability of water resources for irrigation, protective plantations; socio-economic like population displacement, availability of labor resources, material and technical base, market influence and so on. All these factors will have influence on the efficiency of agricultural land use, and will largely define specific management decisions regarding the organization of land, crop rotation, fields, plots, the necessary system of agriculture, agricultural technology, forms of organization of production and labor.

Considerable use of agricultural land in accordance with the requirements of environmental management will have a significant effect, because:

- allow to increase productivity of the lands, that will help to reduce expenses for conducting agrarian business;

- demonstrate to consumers, partners and other categories of stakeholders the compliance of agricultural products with standards, which will enhance the business opportunities of farmers, especially in the context of integration of domestic markets for goods and services into the European trade area;

- provide compliance with regulatory requirements to build confidence from the side of partners, sellers and consumers of agricultural products;

- increase the level of readiness for operational changes of production processes in modern variable business environment in the conditions of permanent intensification of competition.

Following this purpose a certain list of economic regulators of land use has been developed on the state level in the conditions of development of market relations in the agrarian sphere, that is based on the definition of: the normative value of land plots; bases of taxation and value of land tax; fee for land leasing; the market value of land resources; the mortgage price of the land; compensation payments for land conservation; compensation payments for seizure of private property; penalty payments for environmental damage, etc.

The management of above-mentioned tools and its timely application should guarantee economic inspiration for land owners and renters to use it rationally. At the same time, compliance with the environmental management rules will enable the market to be provided with products that meet the high standards of the European Union, which will guarantee domestic producers the ability to compete with importers from neighboring countries.

In Ukraine, the problematic aspects associated with the irrational and inefficient use of agricultural land are gaining ground. One of the objective reasons is the low cost of land ownership, which makes it possible not to use the land for some time for its intended purpose without significant costs.
However, land that is left unattended, devastated and not cultivated is not only a wasted economic resource but also a local threat to the ecology of the region. In this regard, along with measures to increase the administrative responsibility of land users for the non-use and irrational use of agricultural land, it is necessary to increase the level of economic inspiration for farmers to maximize the use of land.

The essence of inspiration to use land rationally in the economic aspect can be interpreted as increasing the level of interest of landowners and land users in preserving and restoring productive potential, protecting land from the negative influence of production activities of economic entities in order to achieve greater effect in the production of agricultural products [13]

Effective ways to organize rational land use on the state level are being followed in foreign practice. The experience of several countries in the world demonstrates a wide variety of tools to provide the rational use of agricultural land. Among the main approaches used abroad are the following:

- seizure of land for public needs and because of public need (construction of roads, schools, energy facilities, etc.);

- regulation of the issue about unused land plots or used in violation of the requirements of the legislation by termination of ownership rights;

- implementation of measures for the organization of rational use and protection of land;

- qualification and other requirements used to identify fraudulent land rights purchasers as well as land owners and users.

Studying foreign experience of taxation of agricultural land resources indicates the need to create such a system of taxation, which should be based on a scientific classification of land. On its basis, the state regulators should form a scale of land tax rates in dependence on the category of land use, type of agricultural land, its ameliorative condition, level of soil fertility, etc.

The method of assessing the level of rational agricultural land use may became an effective tool for stimulating the rational use of agricultural land. The offered by the authors method involves a step-by-step approach to assessing the level of rational agricultural land use.

In particular, the first step is to define the list of indicators for assessing; that are selected, in the opinion of the authors, some of the most representative coefficients in addition with the author's figures.

In the second stage, an information and analytical base are selected, that is, sources of information, the use of which allows obtaining data to calculate the selected indicators.

In the third stage, benchmarks are established to assess the calculated values of the indicators and a system of its scoring is offered.

In the fourth stage, a hypothesis about the feasibility of defining the final indicator of the level of rational agricultural land use is put forward, the value calculation of which will be carried out by defining the sum of valuation that are selected in the first stage of indicators. 
And in the final, fifth stage, the scale of transformation of quantitative assessment for the final indicator into qualitative characterization of the level of rational agricultural land use is carried out.

The offered approach to the formation of methodology for assessing the level of rational agricultural land use allows to obtain a comprehensive and effective information tools for making informed administrative decisions about the application of economic inspiration to the rational agricultural land use and to select specific forms of such inspiration.

The use of the offered methodological approach on the state level should be the first step in the implementation of the task of maintaining the leading role of the state in the development and modernization of the mechanism of rational agricultural land use and land management in the process of forming multicomplex land-market relations and privatization of agricultural land, study and assessment of land resources, organization of its rational use and protection that of unwarranted seizures, degradation, erosion, heavy metal contamination and the prevention of other factors that have adversely influence on the soil cover.

The effective use of agricultural land is connected with the improvement of the land assessment system, which creates the basis for the formation of a set of economic regulation tools for this process. In view of this, it can be concluded that the transition to a new stage of regulation of land relations, the stage of formation of an effective owner of agricultural land is necessary, and the sooner this is done, the closer the prospect of creating favorable conditions for the development of agriculture and the national economy will become.

In addition, forms to provide effective agricultural land use can be:

- $\quad$ seizure of land in case of improper use;

- differentiation of land tax rates towards its increase in case of inefficient use of land;

- assistance to agricultural enterprises in accumulating the fund of unclaimed land shares;

- development of lease relations with the creation of transparent and effective mechanisms for acquiring land rights.

The main economic approaches to the regulation of land relations in modern economic conditions should be:

- the priority of environmental criteria and indicators over economic in land relations;

- predominance of long-term socio-economic programs and approaches over short-term needs;

- comprehensiveness in solving environmental problems and tasks related to the reclamation of disturbed lands, the conservation of degraded and low-productive lands, the prevention of water and wind erosion by the construction of anti-erosion hydraulic structures;

- investing in soil fertility restoration;

- integration and mutual harmonization of the natural, resource, material and technical components of the overall resource-production potential of the agricultural sector;

system in solving environmental problems of the agroindustry [14].

The rational use of agricultural land is possible only if the principles of environmental management are respected during the production of agricultural products. Foremost, it is the formation of environmental consciousness among landowners and land users as the basis of economic activity. In addition, it is a motivation for independent solving and/or prevention of environmental problems that appear because of agricultural land use; prevention of possible critical and irreversible consequences for the environmental situation in the region because of inefficiently organized agricultural production processes; the existence of clear goals and strategies for environmentally oriented use of agricultural land; consistent elimination of environmental problems and the priority of this elimination; timely identification of the moment that allows most effectively eliminate the environmental problems which have arisen in the process of agricultural land use.

\section{CONCLUSIONS}

State management of land resources in the modern conditions of economy is particularly relevant. Land is one of the main resources that is used in economic processes to carry out different types of activity. Land is the main resource for conducting agriculture. In turn, agricultural production is the basis of food security of the state, a prerequisite for economic development and social well-being of any country. Therefore, the distribution and control over the use of agricultural land resources is carried out on the state level under the close supervision of the public and different control bodies.

Modern ways to organize the rational land use on the state level combine incentives for rational agricultural land use and a system of penalties for failure to comply with the land use standards which are established by the state. Current methods of promoting the rational use of agricultural land are to provide tax and credit benefits; exemption from land fee; compensation to agricultural producers of the lost income share because of land conservation; the use of accelerated depreciation. In addition, it is offered to develop the basics of policy and legislative support of regulatory processes for agricultural land management; increase the amount of the fine for violation of the land legislation; differentiate land tax in dependence on the environmental level of economic activity and the condition of application of environmental management principles; differentiate taxes, fees and penalties in dependence on the level of actual violation of standards and regulations in the field of land use and protection; to develop electronic administrative services in the field of land relations on the principle of its extraterritoriality.

Effective use of land resources of Ukraine in the conditions of digital economy will be possible due to the optimal combination of economic and administrative management methods, which should be embodied in the complex economic mechanism of rational agricultural land use, which should be implemented on the state level. The development of such a mechanism is the purpose of further scientific researches in the subject of the chosen research. 


\section{REFERENCES}

1. O. Harnaha, "The theoretical basis to ensure rational land use", Economist, 12, 2011, pp. 41-44.

2. O. Isachenko, and V. Somochkin, "The leading role of public land in the organization of environmental management" Land Management and Cadastre, 1, 2014, pp. 10-19.

3. M. Ievtushenko, "The use of state mechanisms in the implementation of the concept of rational land use and areas of improvement", Bulletin of Kharkov national University named after V. N. Karazin, 970, 2011, pp. 242-245.

4. O. Bryndzia, "Economic levers systematic approach to sustainable agricultural land use", Science and economics, 2, 2014, pp. 99-105.

5. O. Palenychak, "Economic incentives promoting sustainable agricultural land use", Sustainable Nature, 1, 2014, pp. 69-72.

6. M. Stupen, and O. Skorupska, "Economic aspects of land use for agricultural purposes", Bulletin of Lviv national agrarian University, 21(1), 2014, pp. 389-395.

7. L. Shashula, "The role of organic agriculture in the economic provision of environmental management", Sustainable Nature, 1, 2014, pp. 389-395.

8. A. Dubrovyk-Rokhova (2018, April 12). Digitization is just the beginning. [Online]. Available: https://day.kyiv.ua/uk/article/ekonomika/didzhytalizaciya -ce-lyshe-pochatok

9. I. Yasinetska, O. Petrishche, and I. Kovtyniak, "State land castle as a informational base", Economy and Society, 14, 2018, pp. 680-685.

10. A. Palyvoda (2019, September 27). "State in the smartphone": a good, but far from realized idea [Online]. Available:

https://dt.ua/macrolevel/derzhava-v-smartfoni-garna-aledaleka-vid-realizaciyi-ideya-324756 .html

11. A. Martyn (2017, July 3). State Land Cadastre: Where Are We Going? [Online]. Available: https://agravery.com/uk/posts/author/show?slug=derzavn ij-zemelnij-kadastr-kudi-jdemo

12. O. Sakal (2019, September 3). White Land Market: Reality and Expectations [Online]. Available: https://www.epravda.com.ua/publications/2019/09/3/651 218/

13. R. Boichenko (n.d.). Economic incentives for sustainable use and protection of agricultural land [Online]. Available:

http://repo.sau.sumy.ua/bitstream/123456789/2298/1/EK $\mathrm{OHOM} 1 . \mathrm{PDF}$

14. M. Stupen, S. Rohach, and I. Rii, "The mechanism of economic regulation of land relations", Ekonomist, 2, 2015, pp. 42-43.

\section{AUTHORS PROFILE}

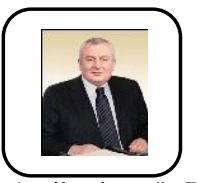

Anatoliy Danylenko. Higher education in the fields of "Veterinary", "Biologist", "Surveying engineer". Candidate of Economic Sciences in the specialty "Business Economics and Managing Forms". Doctor of Economics in the specialty "Agricultural Economics and Agribusiness", Professor, Member of the National Academy of Agrarian Sciences of Ukraine. He has over 130 scientific papers, including 4 articles, published in periodicals, which are included in Scopus and Web of Science international scientific databases. Fields of scientific research: improvement of organizational and economic mechanism for ensuring sustainable development of the agrosphere; development of business in the agro-industrial complex of Ukraine (theoretical and applied aspects); new approaches and management methods involving the innovative experience of countries; organizational and scientific support of land reform, problems of land management, state land cadastre, land monitoring, state control of use and protection of land. Member of Parliament of Ukraine; Chairman of the
Committee of Verkhovna Rada of Ukraine on Agriculture, Land Resources and Social Development of the village; Head of Cherkasy Regional State Administration; Member of the Kyiv Regional Council; Chairman of the commission on education and science, culture, spirituality and religion; Member of the National Academy of Agrarian Sciences of Ukraine of the Department for Scientific Support of Innovation Transfer; Chairman of the Dissertation Advisory Committee Д 27.821.03; Member of the editorial board of the collection of scientific articles "Economics and Management of the Agriculture". He has been awarded with the Order of Honor, the Order of Merit of the 3rd degree, the gold and two silver medals of the Exhibition of National Econome Achievements (VDNKh) of the USSR. He has the title of Honored Agricultural Worker and the badge of Excellence in Education of Ukraine. He participated in the drafting of 10 laws of Ukraine, 2 presidential decrees, author and co-author of 43 proposals to governmental agencies.

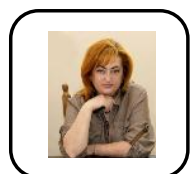

Larysa Satyr. Higher education in the field of economics and organization of agricultural production. Candidate of Economic Sciences in the specialty "Business Economics and Production Organization". Doctor of Economics in specialty Economics and Business Management, Professor, Member of the Academy of Economic Sciences of Ukraine. She has more than 120 scientific and methodological works, including 8 monographs, 5 textbooks, 75 articles, including three articles in periodicals that are included in Scopus and Web of Science international scientific bases. Field of research: evaluation the use of resource potential of agricultura production, including the study of reproductive processes of agricultural material resources in the context of agribusiness development. Member of the Ukrainian Congress of Agrarian Scientists of Economics. Member of the editorial board of the Ukrainian Scientific and Production Journal "Sustainable Development of Economy" and "Economics and Management of Agriculture." She has completed scientific topic of research "Ensuring the parity of relations between agriculture and manufacturer of material and technical resources". She is now the head of the research topic "Improving information and analytical support for the study of business development in institutional sectors of the national economy". She completed a training in Economics with the title of the Work: Modern Methods of Business Processes Management in the Organization (Poland), 2016 and the Institute for European Policy (Germany) Certificate has successfully completed the training of the Civic School for Sound EU, 2019.

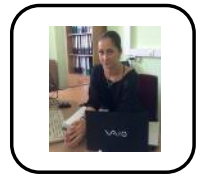

Victoria Novikova. Higher education in the field of social informatics. Candidate of Economic Sciences in the specialty "Mathematical Methods, Models and Information Technologies in Economics". According to the scientific direction, "reliability of forecasts of macroeconomic parameters" she published 32 works, of which 3 monographs, 5 textbooks and study guides, 19 articles. She participated in 17 international and 20 nationwide conferences and completed internship, experience exchange. Esasmus + Institutional Coordinator. Agreement between Bila Tserkva National Agrarian University and the University of Natural Sciences in Prague (CULT) within the ERASMUS+ academic mobility program for teaching. Topics of lectures: 1. "Forecasting of social and economic processes" 2. "Methods of forecasting. Quality management of forecasting methods." 3. "Forecasting of social and economic processes" 4. "The agri-food sector in Ukraine: current situation and market outlook until 2025" In 2018 she completed the international internships: 1.PhDWorkshop "Analysis and forecasting models of inflation based on fuzzy decision tree" 2013 (Germany). 2. Modern teaching methods in economics on the EU educational market" the title of the Work April-May 2018. (Poland). 3. Bila Tserkva National Agrarian University, seminars and training workshops within the framework of the Ukrainian-Czech project "Supporting the Potential of University Youth of Ukraine in Educational and Scientific Activities", 2019 4. International Summer School "Agri-Cooperatives and Institutions for Rural Development" of the Ukrainian-Czech Project "Supporting the Potential of University Youth of Ukraine in Education and Science" with the support of the Czech Republic Development Coperation Agency, 2019.

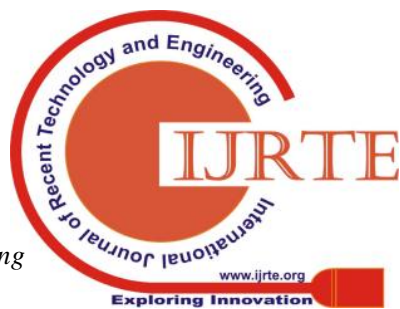


Olena Shust. Higher education in the specialty "Finance". Candidate of Economic Sciences in the specialty "Productivity and Regional Economics". Doctor of Economics in the specialty "Economics and National Economy Management", Professor. She has more than 80 scientific publications, most of which published in Ukrainian and international professional journals, including 5 scientific articles in periodicals included in Scopus and Web of Science international scientific databases. Fields of research: ensuring the competitiveness and innovation of agri-food chains based on the principles of sustainability; rural development in the context of activation of globalization and Euro-integration processes; competitiveness of Ukrainian agricultural sector enterprises in the context of European integration. She is a member of the Dissertation Advisory Committee at Bila Tserkva National Agrarian University; member of the editorial board of the scientific professional periodical "Sustainable Economic Development"; member of the editorial board of the collection of scientific articles "Economics and Management of the Agriculture"; head of the initiative theme of the research work "Competitiveness of the Enterprises of the Agrarian Sector of Ukraine's Economy within the framework of European integration". She prepares the educational component for the Doctor of Philosophy training in the specialty "Economics". In 2018, she received a certificate attesting her high level of English proficiency; trained in Germany at Justus Liebig University (Giessen), 2018. 